The Right to Strike in International Law, by JeffreyVogt, JaniceBellace, LanceCompa, K.D.Ewing, LordHendy QC, KlausLorcher and ToniaNovitz. Oxford/New York: Hart/Bloomsbury, 223 pp., ISBN: 9781509933556 (hardback), 9781509933570 (Epub). 65 hardback, 58.50 Ebook.

Prior, Margaret

http://hdl.handle.net/10026.1/18245

10.1111/bjir.12595

British Journal of Industrial Relations

Wiley

All content in PEARL is protected by copyright law. Author manuscripts are made available in accordance with publisher policies. Please cite only the published version using the details provided on the item record or document. In the absence of an open licence (e.g. Creative Commons), permissions for further reuse of content should be sought from the publisher or author. 


\title{
The Right to Strike in International Law
}

\author{
Jeffrey Vogt | Janice Bellace | Lance Compa | K.D. Ewing | Lord \\ Hendy QC | Klaus Lörcher | Tonia Novitz
}

Oxford/New York: Hart/Bloomsbury, 223 pp., ISBN: 9781509933556 (hardback), 9781509933570 (Epub). £65 hardback, $£ 58.50$ Ebook.

At the 2012 International Labour Conference, the Employers' Group claimed that international law does not grant the right to strike. This claim, the culmination of several years of argument on the issue, called into question decades of understanding and indeed was the first time that any of the three partners in the International Labour Organisation (ILO) had rejected 'an entire area of law, based on its own unique beliefs' (p. 9). It therefore created an unprecedented rift in the ILO which has, to date, been accommodated but not resolved. The stance taken by the Employers' Group is as much to do with the relative authority of the different committees of the ILO, and by implication their ability to influence decisions, as it is to do with the right to strike per se (Thomas and Turnbull 2020). Nonetheless, the suggestion that international law does not give workers the right to withdraw their labour is a major concern, not only for the Workers' Group at the ILO but also for a number of governments.

Opening with a useful guide to the ILO and its processes, this book painstakingly deconstructs the three arguments made by the employers. At issue is the interpretation of ILO Conventions, treaties which, once ratified, are binding on member states. First, the employers claim that only the International Court of Justice can interpret ILO Conventions and not, as has been the case since its formation in 1926, the independent Committee of Experts on the Application of [ILO] Conventions and Recommendations (Committee of Experts). Second, and similarly, the Employers' Group state that only the constituent groups of the ILO, and not the Committee of Experts, can have the ultimate say on the meaning of Conventions. Third, the employers argue that the right to strike is not explicitly stated in ILO Convention no. 87 on Freedom of Association and Protection of the Right to Organise (1948). The Committee of Experts has consistently interpreted this as incorporating the right to strike; however, since the employers argue that the Committee of Experts do not have this authority, they claim that the Convention does not grant the right to strike.

At the heart of The right to strike in international law is a step-by-step rebuttal of the employers' case. The authors, an international parade of lawyers and academic specialists in the field of international collective labour law, highlight the terms of the Vienna Convention on the Law of Treaties, which lays down the rules for the interpretation of treaties, including ILO Conventions. Moreover, they also point out that 'the right to strike has been part of the ILO's DNA from its foundation' (p. 5), presenting evidence that the drafters of the ILO Constitution (1919) assumed from the outset that the right to freedom of association, a central tenet of the ILO, incorporates the right to strike. 
Turning to Convention 87, the book addresses the meaning and application of Article 3, which grants workers' and employers' associations the right to 'draw up their constitutions and rules', to 'organise their administration and activities' and to 'formulate their programmes', all without undue interference from 'the public authorities'. Drawing on numerous decisions, the authors demonstrate how this includes the right to strike, regardless of the absence of any specific point to this effect. In particular, they provide evidence to imply a right to strike not only in the context of the right of trade unions to make their rules, formulate their programmes and plan their activities but also as part of the right of workers and their organizations to bargain collectively, which is protected under Convention no. 98 on The Right to Organise and Collective Bargaining (1949). The major flaw implicit in the Employers' Group claim is a perception of the right to freedom of association as a matter of individual liberty, conferring 'no more than the right to gather together into organisations, be they book clubs or trade unions', when in fact 'the right to freedom of association has long been understood as a collective right, particularly in the context of industrial relations' (p. 52). Indeed, to quote a decision in the German Federal Labour Court, the right to collective bargaining without the right to strike is simply 'collective begging' (p. 55).

Not content with rebutting the claims set out by the Employers' Group, the authors also set out the ways in which the right to strike has been shown to be enshrined in other ILO Conventions, international and regional human rights instruments, trade agreements and the constitutions of no less than 98 states. In short, 'the right to strike is a customary international law norm ... [;] there is an international consensus that the right exists' (p. 168).

The Right to Strike in International Law has its origins in work undertaken for the International Trade Union Confederation at a time (2013-2014) when it appeared that the dispute over the employers' claims would be referred to the International Court of Justice. As such, therefore, it is a scholarly legal document which will be of interest to students and practitioners of collective labour law and scholars of decision making in international organizations. At the same time, however, it is written and presented in an accessible way, with the minimum of legalese, making it a useful handbook for trade unionists, industrial relations academics and students and anybody with a wider concern for fairness and equity at work.

Margaret Prior

University of Plymouth

Email: margaret.prior@plymouth.ac.uk

\section{O R C I D}

Margaret Prior (D) https://orcid.org/0000-0001-6198-4419

\section{REF E R EN C E}

Thomas, H. and Turnbull, P. (2020). “From a "moral commentator" to a "determined actor"? How the International Labour Organisation (ILO) orchestrates the field of international industrial relations'. British Journal of Industrial Relations. https://doi.org/10.1111/bjir.12578 